\title{
Anaeroplasma abactoclasticum gen.nov., sp.nov.: an Obligately Anaerobic Mycoplasma from the Rumen
}

\author{
ISADORE M. ROBINSON, MILTON J. ALLISON, AND PAUL A. HARTMAN \\ National Animal Disease Center, Agricultural Research Service, U.S. Department of Agriculture, and \\ Department of Bacteriology, Iowa State University, Ames, Iowa 50010
}

Obligately anaerobic, filterable microorganisms have been isolated from the rumens of cattle and sheep. On the basis of typical colonial appearance, lack of cell wall, filterability through a 450-nm membrane filter, absence of reversion to a bacterial form, and inhibition of growth by homologous antiserum, these organisms fit the description for organisms in the order Mycoplasmatales. They exhibit unique cultural, biochemical, and serological properties, and we have thus placed them in a new genus, Anaeroplasma. A. abactoclasticum is the type species of the new genus. Strain 6-1, a sterol-requiring strain, has been designated as the type strain of $A$. abactoclasticum and has been deposited in the American Type Culture Collection as ATCC 27879; a non-sterol-requiring strain, number 161, has been deposited as ATCC 27880. The relationship of Anaeroplasma abactoclasticum to Acholesplasma bactoclasticum, an anaerobic mycoplasma possessing extracellular proteolytic and bactoclastic enzymes, is discussed.

In 1966, Hungate (13) described an obligately anaerobic rumen microorganism that lysed bacterial cells. Subsequently, the organism was characterized by Robinson and Hungate (21) as a mycoplasma. The mycoplasma possessed lytic enzymes that caused the partial digestion of killed gram-negative bacteria or casein.

Using methods similar to those of Robinson and Hungate (21), we also isolated bacteriolytic mycoplasmas from the rumens of cattle and sheep. In addition, we discovered that anaerobic mycoplasmas not digesting bacterial cells were present at higher concentrations than the lytic agents.

This paper describes the results of experiments conducted to characterize these new mycoplasmas and contains a proposal for placing them in a new genus.

\section{MATERIALS AND METHODS}

Media. Primary isolation medium (PIM) was similar to medium 98-5 previously used to culture rumen bacteria (7), except that autoclaved Escherichia coli cells $(0.5 \%$, wt $/ \mathrm{vol})$ and penicillin $G(1,000 \mathrm{U} / \mathrm{ml})$ were added.

Clarified rumen fluid broth (CRFB) medium was similar to the PIM, except that Trypticase $(0.2 \%)$ and yeast extract $(0.05 \%)$ were added and the percentages of glucose, cellobiose, and starch were increased $(0.2 \%$ of each instead of $0.05 \%$ ); agar, penicillin, and $E$. coli cells were deleted.

Modified medium 10 (MM-10) was medium 10 of Caldwell and Bryant (10), except that increased concentrations of glucose, cellobiose, and starch $(0.2 \%$ instead of $0.05 \%$ ) were used and sodium sulfide and agar were deleted.

Medium A was similar to MM-10, except that Trypticase was extracted five times by shaking a $2 \%$ (wt/vol) solution with 2 volumes of ethyl ether and yeast extract was replaced by a mixture of $B$ vitamins (8).

Medium B was similar to MM-10, except that $40 \%$ clarified rumen fluid was added and the only carbohydrates used were $6 \mathrm{mg}$ of soluble starch and $2 \mathrm{mg}$ of uniformly ${ }^{14} \mathrm{C}$-labeled starch $(10.3 \mu \mathrm{Ci} / \mathrm{mg}$; Amersham/Searle, Inc., Arlington Heights, Ill.) per $10 \mathrm{ml}$ of medium.

Preparation of media and supplements. The anaerobic methods used were essentially those of Hungate (13) as modified by Bryant and Robinson (7). Media were autoclaved and maintained under anaerobic conditions in rubber-stoppered flasks or tubes with a gas phase of $\mathrm{O}_{2}$-free $\mathrm{CO}_{2} . E$. coli cells were grown in Trypticase soy broth, harvested by centrifugation, washed once with a mineral dilution solution (6), and stored as a frozen pellet. The pellet was thawed and cells were added $(0.5 \%$, wt $/ \mathrm{vol})$ to PIM before the medium was sterilized. A stock solution of cholesterol $(2 \mathrm{mg} / \mathrm{ml})$ was prepared by dissolving 20 $\mathrm{mg}$ of cholesterol in $1 \mathrm{ml}$ of ethanol; the volume was then made to $10 \mathrm{ml}$ with sterile oxygen-free water. Usually the cholesterol was added before the medium was sterilized. Lipopolysaccharide Boivin (LPS-B) (3) and LPS Westphal (LPS-W) (31), both prepared from $E$. coli 0.25 :B6, were purchased from Difco Laboratories. Tests for inhibition of growth by digitonin were carried out in tubes ( 18 by $150 \mathrm{~mm}$ ) containing 10 $\mathrm{ml}$ of MM-10 supplemented with LPS-B $(250 \mu \mathrm{g} / \mathrm{ml})$ and cholesterol $(2 \mu \mathrm{g} / \mathrm{ml})$. A stock solution of digitonin $(2 \mathrm{mg} / \mathrm{ml}$ ) was made by dissolving $20 \mathrm{mg}$ of digitonin 
(Fisher Scientific Co.) in $1 \mathrm{ml}$ of ethanol; the volume was then made to $10 \mathrm{ml}$ with water. In most experiments, the digitonin was added before the medium was sterilized.

Isolation procedures. Isolation procedures were essentially those of Robinson and Hungate (21). Samples of rumen contents from cattle and sheep were obtained from animals fitted with rumen fistulas. A sample of ruminal ingesta was obtained from a deer accidentally killed on the highway, and cecal material from rabbits, hamsters, horses, pigs, and turkeys was obtained at the time of slaughter. Serial dilutions were made in tubes (18 by $150 \mathrm{~mm}$ ) of anaerobic dilution solution (6). Volumes $(0.1 \mathrm{ml})$ of appropriate dilutions were inoculated into tubes of melted PIM held in a water bath at $45 \mathrm{C}$, and the tubes were then rolled in an ice-water bath equipped with a motorized roller. Inoculated roll tubes were incubated at $37 \mathrm{C}$ and periodically examined visually for the presence of colonies surrounded by clear zones due to lysis of the suspended $E$. coli cells. In most cases, discrete zones were seen within $48 \mathrm{~h}$. Furthermore, the roll tubes were examined with a Bausch \& Lomb stereoscopic microscope for the presence of mycoplasma-like colonies that did not produce clear zones.

Pure cultures were picked as individual colonies with a Pasteur pipette and were subcultured in CRFB medium. The cell suspensions in liquid medium were serially diluted in PIM, and colonies were reisolated from roll tubes of the highest dilutions showing growth after incubation at $37 \mathrm{C}$ for $48 \mathrm{~h}$. The lytic or nonlytic properties of these cultures remained stable from primary isolation through all subsequent cultures.

Growth measurements. Growth was usually expressed as absorbance at $600 \mathrm{~nm}$ in tubes (18 by 150 $\mathrm{mm}$ ) and was measured with a Bausch \& Lomb Spectronic 20 colorimeter. Duplicate tubes of medium $(10 \mathrm{ml})$ were usually inoculated with $0.1 \mathrm{ml}$ of an overnight (16- to 18-h) culture grown in CRFB medium. In some experiments, the inoculum consisted of cells washed two times under a $\mathrm{CO}_{2}$ gas phase in anaerobic mineral solution. In most experiments, the maximum absorbance is reported; this usually occurred in less than $48 \mathrm{~h}$.

Assay for urease activity. A $1-\mathrm{ml}$ volume of a washed-cell suspension (cells from $100 \mathrm{ml}$ of culture) was mixed with $0.5 \mathrm{ml}$ of $\left[{ }^{14} \mathrm{C}\right.$ ] urea $(0.2 \mu \mathrm{Ci} / \mathrm{ml}$; specific activity $23.3 \mathrm{mCi} / \mathrm{mmol}$ ) in a rubber-stoppered test tube ( 13 by $100 \mathrm{~mm}$ ) and incubated at $37 \mathrm{C}$ for $0,10,30$, and $90 \mathrm{~min}$ under $\mathrm{CO}_{2}$. Reactions were stopped by injecting $0.2 \mathrm{ml}$ of $2 \mathrm{~N} \mathrm{NaOH}$ through the stopper. The contents in each tube were then assayed (14) for ${ }^{14} \mathrm{CO}_{2}$ resulting from hydrolysis of ['C C jurea.

Analysis of fermentation products. Cultures were acidified by addition of a solution of $25 \%$ (wt/vol) metaphosphoric acid $(1: 4, \mathrm{vol} / \mathrm{vol})$; they were centrifuged at $20,000 \times g$, and volatile fatty acids in the supernatant fluid were determined by gas-liquid chromatography at $115 \mathrm{C}$ with a Teflon column $(2 \mathrm{~mm}$ by $1.5 \mathrm{~m}$ ) packed with $10 \% \mathrm{SP}-1200$ and $1 \% \mathrm{H}_{2} \mathrm{PO}_{4}$ on 80 to 100 -mesh chromosorb WAW (Supelco, Inc., Bel- lefonte, $\mathrm{Pa}$.). The carrier gas was helium and a hydrogen flame detector was used. Gas chromatography was also used to measure ethanol (1), formic acid, and the methyl esters of lactic and succinic acids (12). Lactic acid was also determined by the colorimeter method described by Barker and Summerson (2). Hydrogen was measured on a Beckman GC-2 gas chromatograph equipped with a silica gel column, argon carrier gas, and a thermal conductivity detector.

To measure fermentation products from ${ }^{14} \mathrm{C}$ labeled starch, a culture was grown on medium B. After inoculating the medium with $0.1 \mathrm{ml}$ of a 24-h-old culture and incubation for $16 \mathrm{~h}$, growth was stopped and gaseous $\mathrm{CO}_{2}$ was absorbed by injection of $\mathrm{NaOH}$ through the rubber stopper. Radioactivity in $\mathrm{CO}_{2}$ was measured after acidification and diffusion into $p$-(diisobutyl-cresoxyethoxyethyl) dimethylbenzyl ammonium hydroxide (15).

Radioactivity in cells was measured after cells were washed and solubilized in NCS (Amersham/Searle, Inc.). Radioactivity was measured by using a liquid scintillation counting system (Packard Instrument Co.) with a toluene scintillation solution (11).

The culture supernatant fluid was separated into alkaline-volatile and acid-volatile fractions, and the part that was not acid-volatile was extracted with ether for $48 \mathrm{~h}$. Radioactive products in these fractions were separated by using a method similar to that described by Wainer (28). Materials were passed through an acidic ion-exchange resin column (Beckman AA-15 resin for amino acid analysis; 59 by $9 \mathrm{~cm}$ ) and eluted at $30 \mathrm{C}$ with $0.2 \mathrm{~N}$ sodium citrate, $\mathrm{pH} 4.5$. Radioactivity in the eluate was measured by using an anthracene-packed flow cell (Packard Instrument Co.), and the identity of the labeled substances was deduced by comparison with retention volumes of known labeled compounds on the same column.

Buoy ant density of mycoplasmal DNA. The mole percentage of guanine plus cytosine $(G+C)$ of mycoplasma deoxyribonucleic acid (DNA) was calculated from buoyant density measurements in $\mathrm{CsCl}$ gradients, as described by Schildkraut et al. (22). E. coli B DNA (assumed to have a buoyant density of 1.710 $\mathrm{g} / \mathrm{cm}^{3}$ ) served as a reference.

DNA was extracted at $\mathrm{pH} 9$ from cells (centrifuged from 1 liter of a culture grown in CRFB) by the phenol method of Miura (16), except that ribonucleic acid was eliminated by the acetate-ethylenediaminetetraacetate procedure of Marmur (15). The concentration of the isolated DNA was determined by the diphenylamine colorimetric method of Burton (9). Density was measured after centrifugation in a Spinco model E analytical ultracentrifuge for $18 \mathrm{~h}$ at 44,000 $\mathrm{rpm}$ at $25 \mathrm{C}$. Ultraviolet absorption photographs were taken, and negatives were scanned with a Beckman model RB Analytrol equipped with a thin-film densitometer. A portion of isolated DNA from strain 6-1 was treated with bovine pancreatic deoxyribonuclease I (Sigma Chemical Co., St. Louis, Mo.) and examined in the ultracentrifuge; the buoyant density of the treated DNA was compared with the buoyant density of the untreated DNA.

Electron microscopy. Cells for electron micros- 
copy were obtained from cultures grown in CRFB medium ( 12 to $16 \mathrm{~h}$ ) and harvested by centrifugation. The cells were negatively stained with neutralized phosphotungstic acid by the Brenner and Horne (5) method as modified by Ritchie and Fernelius (19). Thin sections of cells were prepared by the method of Boothe et al. (4).

Grids were examined with a Phillips EM-200 electron microscope (Phillips Electronic Instruments, Mt. Vernon, N.Y.) operated at $60 \mathrm{kV}$.

Filterability. Filterability was determined by diluting a growing CRFB culture $(6 \mathrm{~h})$ in anaerobic dilution solution and by passing the diluted culture through membrane filters. A Swinnex hypodermic adaptor and membrane filters with average pore sizes of 450, 220, and $100 \mathrm{~mm}$ (Millipore Corp., Bedford, Mass.) were used. The concentrations of colony-forming units (CFU) were determined on the original suspension and on the filtrates from each filter used.

\section{RESULTS}

Roll tubes of PIM inoculated with rumen contents of cattle and sheep revealed mycoplasma-like colonies surrounded by clear zones due to lysis of the suspended $E$. coli cells. The clear zones facilitated enumeration and identification of the lytic agent. Table 1 shows counts of anaerobic mycoplasmas in samples of ruminal contents collected at different times from four fistulated cows and three sheep. Lytic mycoplasmas capable of hydrolyzing killed $E$. coli cells or casein (skim milk), or both, were usually present at between $10^{5}$ to $10^{7}$ viable units per $g$ of rumen contents. The colonial morphology and lytic activity were similar to those described for Acholeplasma bactoclasticum, an anaerobic bacteriolytic mycoplasma reported by Robinson and Hungate (21).

When roll tubes containing $E$. coli cells were examined with a stereoscopic microscope, mycoplasma-like colonies that did not digest the cells were detected. In most experiments, the colonies could be observed within $48 \mathrm{~h}$. Nonlytic mycoplasmas were consistently present at higher concentrations (about $10^{7}$ to $10^{8} / \mathrm{g}$ of rumen contents) than those of lytic mycoplasma. Both lytic and nonlytic mycoplasmalike colonies were also observed when PIM that did not contain penicillin was used.

Twenty isolates of non-bacteriolytic mycoplasmas were made from the $10^{6}$ and $10^{7}$ dilutions of ruminal contents from a sheep. Five isolates were selected for further study: strains 6-1 and 171 (required sterol) and strains 161, 162 , and 163 (did not require sterol).

Neither the lytic nor the nonlytic mycoplasma-like colonies were detected in cultures of cecal material from rabbits, hamsters, horses, pigs, and turkeys or of ruminal contents from
TABLE 1. Colony counts ${ }^{a}$ of anaerobic mycoplasmas from the rumens of cattle and sheep

\begin{tabular}{r|l|c|c|c}
\hline $\begin{array}{c}\text { Expt } \\
\text { no }\end{array}$ & $\begin{array}{c}\text { Animal/ } \\
\text { source }^{8}\end{array}$ & Medium $^{c}$ & $\begin{array}{c}\text { Lytic } \\
\text { CFU }\end{array}$ & $\begin{array}{c}\text { Nonlytic } \\
\text { CFU }\end{array}$ \\
\hline 1 & Cow (1) & A & $2.0 \times 10^{6}$ & $d$ \\
2 & Cow (1) & A & $1.4 \times 10^{6}$ & $d$ \\
3 & Cow (1) & A & $2.0 \times 10^{7}$ & $d$ \\
4 & Cow (1) & A & $8.0 \times 10^{6}$ & $4.0 \times 10^{7}$ \\
5 & Cow (2) & A & $2.0 \times 10^{7}$ & $6.2 \times 10^{7}$ \\
6 & Cow (3) & A & $3.5 \times 10^{6}$ & $4.6 \times 10^{7}$ \\
7 & Cow (4) & A & $5.4 \times 10^{6}$ & $2.7 \times 10^{7}$ \\
8 & Sheep (1) & A & $2.1 \times 10^{5}$ & $4.0 \times 10^{7}$ \\
9 & Sheep (1) & B & $2.6 \times 10^{5}$ & $1.7 \times 10^{7}$ \\
10 & Sheep (2) & A & $8.2 \times 10^{6}$ & $3.2 \times 10^{7}$ \\
& & & & \\
11 & Sheep (3) & C & $4.1 \times 10^{7}$ \\
\hline
\end{tabular}

${ }^{a}$ CFU per gram of ruminal contents.

${ }^{\circ}$ Samples were collected from four cows and three sheep at various times over a period of 24 months. Cows 3 and 4 were from a herd at Iowa State University. All other animals were from the National Animal Disease Center.

${ }^{c}$ Medium A, PIM; medium B, PIM minus carbohydrates; medium C, PIM minus $E$. coli cells.

${ }^{d}$ Nonlytic CFU observed but not counted.

e Lytic CFU could not be distinguished from nonlytic CFU because $E$. coli cells were not included in the isolation medium.

deer when dilutions containing $1 \mathrm{mg}$ and less of these materials per culture tube were tested. The methods and medium used for examining cecal materials were those used for ruminal contents.

Colonial morphology. We were not able to distinguish between lytic and nonlytic organisms by colonial morphology. Subsurface colonies were golden, irregular, and often multilobed. Surface colonies had a dense center and a translucent periphery and presented the socalled "fried egg" appearance. The average diameter of surface colonies was about $1 \mathrm{~mm}$.

Cellular morphology. The cellular morphology of the nonlytic organisms was similar to that for Acholeplasma bactoclasticum described by Robinson and Hungate (21). Cells of young cultures ( 12 to $18 \mathrm{~h}$ old) were gram-negative, coccoid elements about $500 \mathrm{~nm}$ in diameter.

Motility was not observed when cells of young cultures (12 to $28 \mathrm{~h}$ old) were examined by phase microscopy, nor were organelles usually associated with motility seen in electron micrographs.

Phase-contrast microscopy of liquid cultures revealed single cells and clumps of cells. Dumbbell forms or clusters of 2 to 10 coccoid cells joined by short filaments were common. In 
electron micrographs of negatively stained preparations (cells from 24-h-old cultures), a variety of pleomorphic forms was seen, including filamentous and budding, or bleb-like, structures.

Thin sections of strain 6-1 prepared for electron microscopy showed cells enveloped by a trilaminar "unit membrane" (7.5 to $10 \mathrm{~nm}$ thick) with no evidence of a cell wall (Fig. 1). Small electron-dense bodies resembling "elementary bodies" were not apparent in sectioned materials.

Effect of oxygen. Growth of these organisms was inhibited by oxygen. The organisms grew in pre-reduced medium maintained in an anaerobic system. If resazurin in a test medium became oxidized, the organisms failed to grow. They did not grow when pre-reduced medium inoculated with the organisms was transferred to petri plates and incubated in an $\mathrm{H}_{2}-\mathrm{CO}_{2}$ atmosphere in a Brewer jar. The inhibitory effect of oxygen on growth was not altered by repeated subculturing of these organisms.

Nutritional and physiological characteristics. All strains grew in a mineral salts medium containing rumen fluid and soluable starch. In studies with strain 6-1, the optimal level of rumen fluid was $40 \%$. In studies with the partly defined MM-10 devoid of other carbohydrates but with $40 \%$ rumen fluid added, the optimal level of starch was $0.2 \%$. Growth was less when maltose, cellobiose, or glucose was substituted for starch. Media containing arabinose, fructose, galactose, glycerol, glucose, mannose, raffinose, salicin, sucrose, or xylose did not support growth. None of the strains grew in rumen fluid-free MM-10 alone or in MM-10 plus cholesterol, and LPS-B was essential for all strains (Table 2). LPS-B $(0.25 \mathrm{mg} / \mathrm{l}$ medium) stimulated growth of strain $6-1$, even when

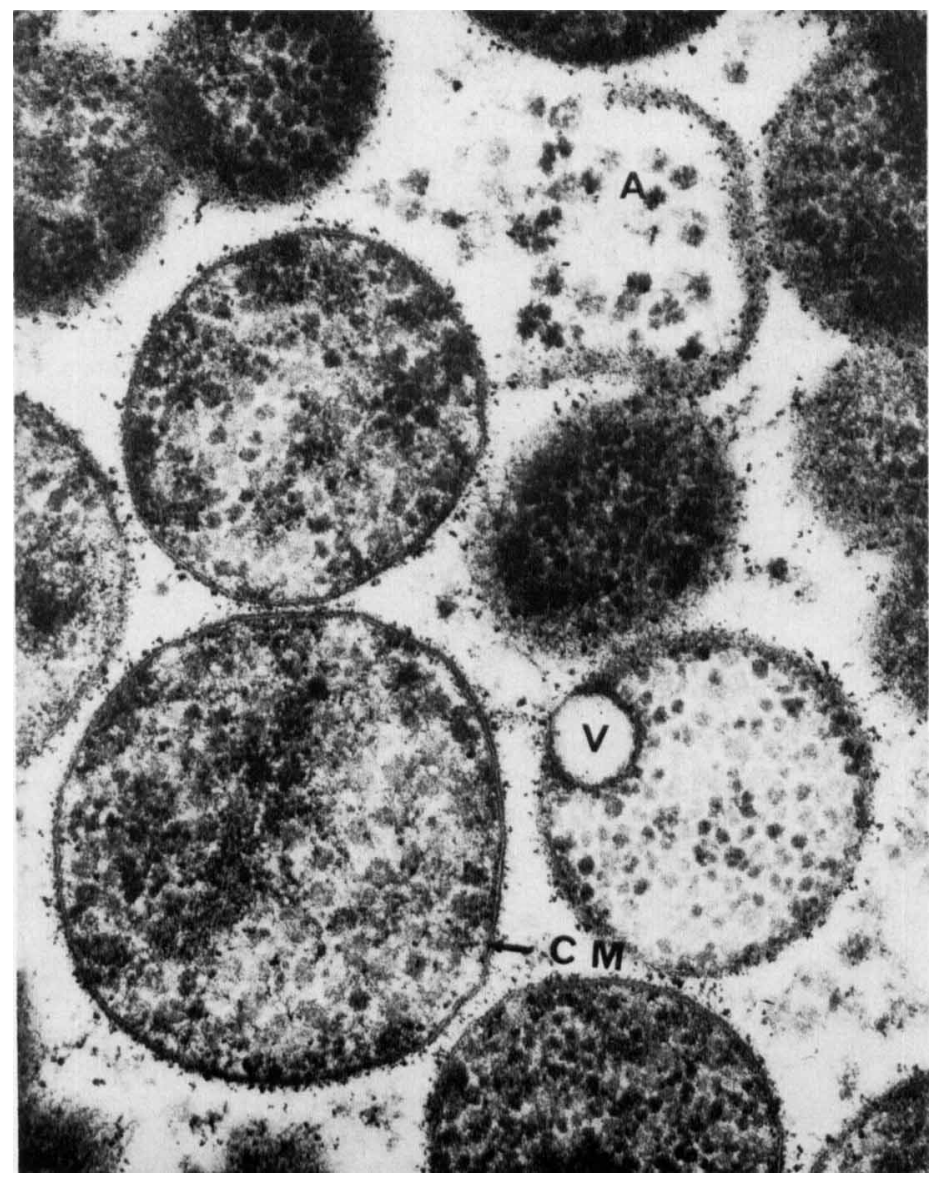

Fig. 1. Anaerobic mycoplasma (strain 6-1); 24-h-old culture. An older cell contains an empty, membranebound vesicle $(V)$. An autolyzed cell $(A)$ is also present. The triluminar cytoplasmic membrane $(C M)$ is readily visible in this electronmicrograph. $\times 67,250$. 
TABLE 2. Growth of anaerobic mycoplasmas in serum-free medium

\begin{tabular}{|c|c|c|c|c|c|}
\hline \multirow{3}{*}{ Medium $^{a}$} & \multicolumn{5}{|c|}{ Growth ${ }^{b}$} \\
\hline & \multicolumn{2}{|c|}{ Sterol-dependent strain } & \multicolumn{3}{|c|}{ Sterol-independent strain } \\
\hline & $6-1$ & 171 & 161 & 162 & 163 \\
\hline \multicolumn{6}{|l|}{ Expt 1} \\
\hline MM-10 & $0(64)$ & $0(36)$ & $0(36)$ & $0(36)$ & $0(36)$ \\
\hline MM-10 + cholesterol $^{c}$ & $0(64)$ & $0(36)$ & $0(36)$ & $0(36)$ & $0(36)$ \\
\hline MM-10 + LPS ${ }^{d}$ & $4(64)$ & $15(14)$ & $36(24)$ & $35(20)$ & $15(20)$ \\
\hline MM-10 + LPS + cholesterol & $40(36)$ & $42(18)$ & $47(24)$ & $45(20)$ & $29(28)$ \\
\hline \multicolumn{6}{|l|}{ Expt $2^{e}$} \\
\hline MM-10 + LPS & $3(72)$ & $1(48)$ & $22(30)$ & $12(30)$ & $40(30)$ \\
\hline MM-10 + LPS + cholesterol & $21(72)$ & $24(38)$ & $34(30)$ & $30(30)$ & $24(30)$ \\
\hline \multicolumn{6}{|l|}{ Expt 3} \\
\hline Medium A + LPS & $0(64)$ & $0(72)$ & $18(21)$ & $22(20)$ & $20(21)$ \\
\hline Medium A + LPS + cholesterol & $69(64)$ & $45(21)$ & $18(21)$ & $28(16)$ & $25(21)$ \\
\hline
\end{tabular}

a See Materials and Methods.

${ }^{\circ}$ Growth was measured turbidimetrically in $18-\mathrm{mm}$ tubes of duplicate cultures and is expressed as the maximum absorbancy at $600 \mathrm{~nm} \times 100$. Numbers in parentheses are hours of incubation for maximum reading. Inocula of washed cells were used in experiments 1 and 3.

c Cholesterol $(20 \mu \mathrm{g} / \mathrm{ml}$ of medium).

${ }^{a}$ Lipopolysaccharide Boivin, $E$. coli $(0.25 \mathrm{mg} / \mathrm{ml}$ medium $)$.

e The third serial transfer of cultures in experiment 1 (MM-10 + LPS) used to inoculate $(0.1 \mathrm{ml} / 10 \mathrm{ml}$ of medium) the same medium and this medium plus cholesterol.

cultured in CRFB medium containing 40\% rumen fluid. However, growth was inhibited by the addition of LPS-W $(0.25 \mathrm{mg} / \mathrm{ml})$.

Cholesterol was essential for the growth of strains 6-1 and 171 but not for the growth of strains 161,162 , and 163 (Table 2). In some experiments, small amounts of cholesterol in materials in the basal medium stimulated growth of cholesterol-requiring strains. Strains 6-1 and 171, for example, grew to a limited extent in MM-10, provided that LPS-B was incorporated in the medium. If growth was too low to be detected turbidimetrically (Table 2, expt. 2), evidence for growth was obtained after three serial transfers at 3-day intervals in MM-10 without added cholesterol, followed by subculture to a medium containing $20 \mu \mathrm{g}$ of cholesterol per $\mathrm{ml}$.

When medium prepared with Trypticase that had been extracted five times with ethyl ether (medium A) was inoculated with washed cells, strains $6-1$ and 171 did not grow unless cholesterol was added (Table 2, expt. 3). Evidence for the absence of growth in medium without added cholesterol was also obtained by serial transfer experiments as described above. Untreated Trypticase evidently contained sufficient cholesterol to support growth of strains 6-1 and 171 .

The growth response to cholesterol in a serum-free medium by cholesterol-requiring and nonrequiring strains is shown in Fig. 2. Strains
6-1 and 171 were greatly stimulated by the addition of $10 \mu \mathrm{g}$ of cholesterol per $\mathrm{ml}$ of medium. Strains 161, 162, and 163 grew without added cholesterol. Growth was only slightly improved when $10 \mu \mathrm{g}$ of cholesterol per $\mathrm{ml}$ was added to the culture medium; however, higher cholesterol concentrations were somewhat inhibitory.

Growth of all strains was less (turbidity measurements were approximately one-half) when the volatile acids were deleted from medium A. Cultures grown without added volatile acids were assayed for production of other fermentation products. All strains produced ethanol and acetic and lactic acids. Hydrogen gas was not detected when $500-\mu 1$ samples of head-space gas were removed from $5-\mathrm{ml}$ cultures in tubes ( 13 by $100 \mathrm{~mm}$ ) and assayed by gas chromatography. The lower limit for detection of $\mathrm{H}_{2}$ was less than $0.33 \mu \mathrm{l}$ per sample.

Growth of the sterol-requiring strains 6-1 and 171 was inhibited by digitonin $(20 \mu \mathrm{g} / \mathrm{ml})$, whereas growth of the nonsterol-requiring strains 161,162 , and 163 was not affected by 200 $\mu \mathrm{g}$ of digitonin per $\mathrm{ml}$ and was only slightly inhibited by $500 \mu \mathrm{g} / \mathrm{ml}$.

Other characteristics. Strain 6-1 failed to grow in CRFB medium incubated at 26 and $47 \mathrm{C}$ for 1 week but grew at $37 \mathrm{C}$. A suspension of cells of strain 6-1 $\left(5.2 \times 10^{6} \mathrm{CFU} /\right.$ $\mathrm{ml})$ was filtered with membrane filters with 


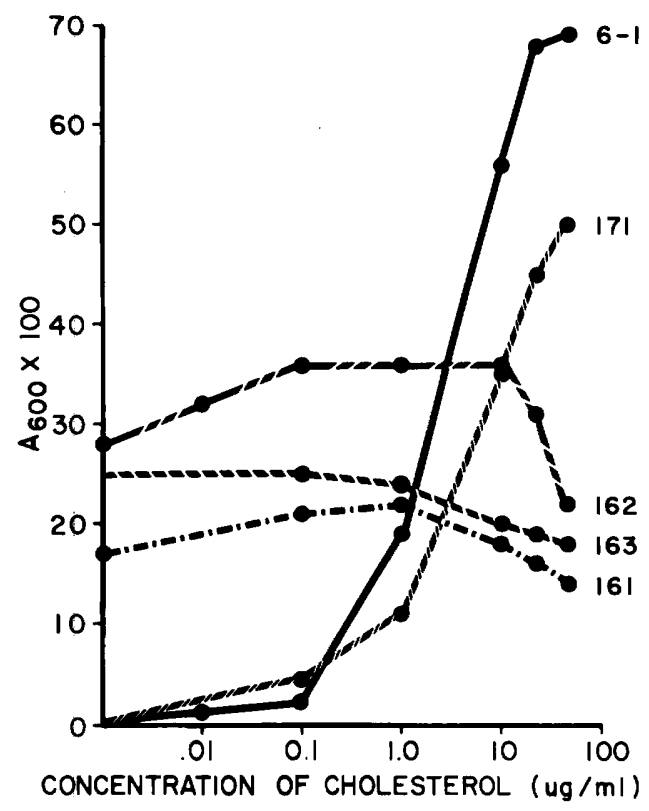

Fig. 2. Growth responses of anaerobic mycoplasmas to cholesterol concentrations in a serum-free medium. The basal medium was medium A. Growth of duplicate cultures was measured turbidimetrically in test tubes (18 by $100 \mathrm{~mm}$ ) and expressed as maximum absorbancy at $600 \mathrm{~nm} \times 100$.

average pore size designations of 450,200 , and $100 \mathrm{~nm}$. The filtrates contained $5.3 \times 10^{5}$, $6.9 \times 10^{2}$, and $0 \mathrm{CFU} / \mathrm{ml}$, respectively. Thallous acetate $0.2 \%(0.75 \mu \mathrm{mol} / \mathrm{ml})$, bacitracin $(0.7 \mu \mathrm{mol} / \mathrm{ml})$, streptomycin $(0.36 \mu \mathrm{mol} / \mathrm{ml})$, and D-cycloserine $(5 \mu \mathrm{mol} / \mathrm{ml})$ inhibited growth of strain 6-1 when added to CRFB medium. The addition of $0.5 \mathrm{mg}$ of penicillin $\mathrm{G}$ per $\mathrm{ml}(1,000$ $\mathrm{U} / \mathrm{ml}$ ) to the medium did not inhibit growth. No reversion to a bacterial form has been observed during numerous subcultures of some strains over a 2-year period in media devoid of penicillin. Tests of washed cells of strain 6-1 for the presence of urease, based upon enzymatic production of ${ }^{14} \mathrm{CO}_{2}$ from $\left[{ }^{14} \mathrm{C}\right]$ urea, were negative. Arginine $(0.1 \%$ final concentration $)$ was not metabolized when added to a test medium as the only energy source.

The $\mathrm{G}+\mathrm{C}$ base composition of DNA isolated from strain 6-1 was calculated to be $29.3 \mathrm{~mol} \%$. The buoyant density was $1.690 \mathrm{~g} / \mathrm{cm}^{3}$ relative to DNA of E. coli at a density of $1.710 \mathrm{~g} / \mathrm{cm}^{3}$ (Fig. 3). The density band at $1.690 \mathrm{~g} / \mathrm{cm}^{3}$ did not appear when the isolated DNA was treated with deoxyribonuclease. A small satellite band with a density of $1.670 \mathrm{~g} / \mathrm{cm}^{3}$ appeared in four gradients and is unexplained. The DNA isolated from sterol-requiring strain 171 had a $\mathrm{G}+\mathrm{C}$ content of $29.5 \mathrm{~mol} \%$, very close to the $\mathrm{G}+\mathrm{C}$ content of strain 6-1. Under the same conditions, two non-sterol-requiring strains, 161 and 162 , had $\mathrm{G}+\mathrm{C}$ values of 40.2 and $40.3 \mathrm{~mol} \%$, respectively.

The distribution of ${ }^{14} \mathrm{C}$ in fermentation products from strain 6-1 grown in medium containing uniformly ${ }^{14} \mathrm{C}$-labeled starch is shown in Table 3. Acetic and formic acids were the only labeled volatile acids detected. Lactic acid was

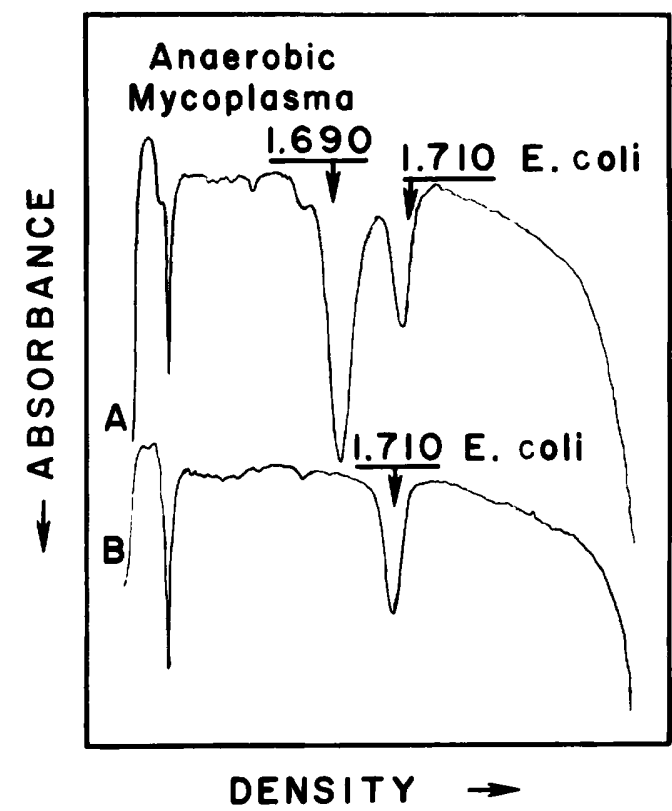

FIG. 3. Microdensitometer tracings of DNA isolated from strain 6-1, equilibrated in a $\mathrm{CsCl}$ gradient formed by centrifugation at 44,000 rpm. The band at 1.710 is DNA from $E$. coli $B$, added as reference. The band at 1.690 in $(A)$ did not appear when DNA from strain 6-1 was treated with deoxyribonuclease $(B)$. Minor bands of very light density were not identified.

TABLE 3. Distribution of radioactivity in metabolic products of strain 6-1 grown in a medium ${ }^{a}$ containing uniformly ${ }^{14} \mathrm{C}$-labeled starch

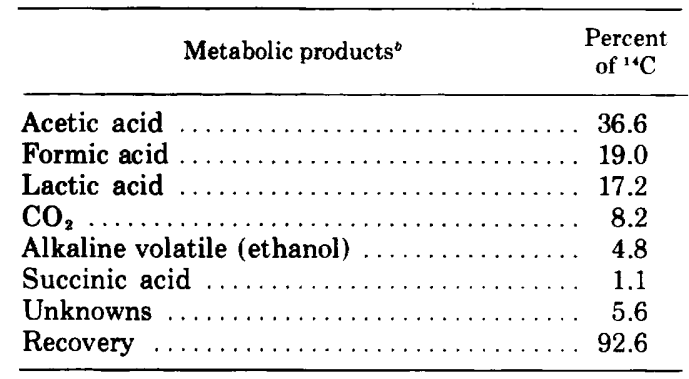

${ }^{a}$ Medium B.

${ }^{\circ}$ Identified as given in Materials and Methods. 
the main nonvolatile product. Small amounts of ${ }^{14} \mathrm{C}$ were detected in succinic acid, $\mathrm{CO}_{2}$, and several unidentified products.

In consideration of the foregoing, we propose that these obligately anaerobic microorganisms be assigned to a new genus, as follows. Anaeroplasma gen.nov. Gr. prefix (an without; Gr. mas.n. aer air; Gr. neut. noun plasma a form; M. L. neut. noun Anaeroplasma intended to denote "anaerobic mycoplasma"). Obligately anaerobic. Cells of young (16- to 18-h-old) cultures are coccoid, about $500 \mathrm{~nm}$ in diameter, gram negative, and nonmotile; older cells have a variety of pleomorphic forms. In wet-mount preparations examined by phase microscopy, there are single cells, clumps, and dumbbell forms; clusters of 2 to 10 coccoid forms joined by short filaments are often seen. Electron micrographs of thin sections show cells bounded by a typical trilaminar membrane with no distinguishable cell wall. Subsurface colonies are golden, irregular, and often multilobed. Surface colonies have a dense center and translucent periphery and present a "fried-egg" appearance characteristic of many mycoplasmas. Insensitive to penicillin. Starch is fermented to produce various acids (generally acetic, formic, propionic, lactic, and succinic), gases $\left(\mathrm{CO}_{2}\right.$; some strains produce $\mathrm{H}_{2}$, see J. P. Robinson, Diss. Abstr. Int. B 32: 7196, 1972), and ethanol. Strain variations exist in fermentation of other carbohydrates. One species produces an extracellular enzyme(s) that hydrolyzes cell walls of dead gram-negative bacteria (including mixed populations of ruminal bacteria, $E$. coli, and Pasteurella multocida). Both sterol- and nonsterol-requiring strains occur. Found in the rumens of cattle and sheep.

Sterol-requiring strain 6-1 is designated as the type strain of the new species Anaeroplasma abactoclasticum sp.n. (Gr. prefix a without; bact part of the stem of the Gr. dim. noun bacterium a small rod; Gr. adj. clasticum breaking; M. L. adj. abactoclasticum intended to denote "not bacteriolytic"). Strain 6-1 has been deposited in the American Type Culture Collection under the number ATCC 27879.

The species A. abactoclasticum has the characteristics of the genus as given above except that it lacks the extracellular bactoclastic and proteolytic enzymes that characterize the lytic species, and none of the strains produced hydrogen. It is gram negative, usually coccoid, and has a cell envelope with a "unit membrane" structure.

The DNA base ratio of the type strain $(6-1)$ is $29.3 \mathrm{~mol} \%$. Growth is inhibited by digitonin (20 $\mu \mathrm{g} / \mathrm{ml}$ ) and thallous acetate but not by penicil- lin. Starch, maltose, and cellobiose are fermented. Fermentation products from starch include: carbon dioxide, ethanol, and acetic, formic, lactic, and succinic acids. Arginine is not used as an energy source; urea is not hydrolyzed. In rumen fluid-free medium, a factor present in LPS is required for growth.

Strains 161,162 , and 163 are similar to the type strain 6-1 except that they are cholesterol independent. They are not inhibited by digitonin, and the $\mathrm{G}+\mathrm{C}$ contents of two strains (161 and 162) on which these determinations were made were 40.3 and $40.5 \mathrm{~mol} \%$, respectively. Strain 161 has been deposited in the American Type Culture Collection as ATCC 27880 and is representative of the non-sterol-requiring strains. The possible assignment of these strains to a species of Anaeroplasma awaits further studies.

\section{DISCUSSION}

The obligately anaerobic nature of the mycoplasmas reported here distinguishes them from other mycoplasmas that have been described previously, although mycoplasmas that require reduced oxygen tension for initial isolation but lose this requirement upon repeated subculture have been described $(24,27)$. Strictly anaerobic conditions are required for the growth of the organisms described in this study even though they have been transferred more than 50 times over a 2-year period. Furthermore, the finding that a plasmalogen (alk-1-enyl glyceryl ether) is a major component of polar lipids from these organisms (T. A. Langworthy, W. R. Mayberry, P. F. Smith, and I. M. Robinson, manuscript in preparation) supports the concept that these organisms are distinct from aerobic mycoplasmas since plasmalogens appear to be unique to anaerobic microbes.

The physiological characteristics of these mycoplasmas (substrate, $\mathrm{eH}$ and temperature requirements) suggest that they are well adapted for survival in the rumen. The appearance of these organisms in PIM with penicillin deleted indicates that they are natural inhabitants of the rumen and are not L-forms produced by the presence of penicillin. The fact that growth of strain 6-1 was inhibited by D-cycloserine was unexpected and without explanation. Available evidence indicates that D-cycloserine acts by interfering with cell wall biosynthesis (29). The inhibitory concentration $(5 \mu \mathrm{mol} / \mathrm{ml})$ was much lower than that reported for a number of other mycoplasmas (29).

Because gram-negative organisms are major components of the ruminal population, one 
might expect LPS to be present in ruminal contents. Robinson (Diss. Abstr. Int. B 32: 7196, 1972) reported stimulation of his bacteriolytic mycoplasma by LPS extracted from $E$. coli with phenol. To our knowledge, however, a nutritional requirement for LPS has not been reported previously for mycoplasmas or for other bacterial species. The requirement for LPS in rumen fluid-free medium appears to be common to this group of mycoplasmas. The fact that LPS prepared by the Boivin (3) method (LPS-B) from $E$. coli stimulated growth of strain 6-1 whereas the Westphal (30) preparation (LPS-W) from the same strain inhibited growth may give some clue as to the components responsible for growth stimulation. The trichloroacetic acid extraction procedure of Boivin yields LPS contaminated with residual peptides that are removed in the phenol procedure of Westphal. We do not know whether these peptides are the factors that promoted growth or whether residual phenol in the phenol-extracted preparation might have inhibited the mycoplasmas.

Some, but not all, mycoplasmas require sterols for growth, a characteristic that is used to separate the order Mycoplasmatales into two families (26): Mycoplasmataceae, organisms that require sterols for growth; and Acholeplasmataceae, organisms that do not require sterols for growth. The amount of cholesterol required to initiate growth varies with the strain, and the requirement for sterol is often difficult to show, especially in media containing crude materials. Robinson (Diss. Abstr. Int. B 32: 7196, 1972) reported that two samples of rumen fluid assayed by the ferric chloride method contained the equivalent of 4.39 and $4.33 \mu \mathrm{mol}$ of cholesterol per ml. Contrary to the general assumption that bacteria are incapable of synthesizing sterols, Schubert et al. (23) identified sterols in $E$. coli and other bacteria. We were able to show an absolute requirement for cholesterol with some strains only if the Trypticase used to prepare the medium had been extracted with ether. Thus, the requirement for cholesterol by some strains apparently cannot be assessed if the growth medium contains rumen fluid, $E$. coli cells, or Trypticase. Although the requirement for cholesterol is regarded as the most important criterion for distinguishing the genus Acholeplasma from Mycoplasma, the procedure used to establish this requirement must be carefully controlled (18).

Cholesterol requirement may also be determined by the selective sensitivity of sterolrequiring mycoplasmas to digitonin. Digitonin sensitivity seems to parallel ability of the microorganisms to incorporate cholesterol $(17,25)$. Species that require cholesterol for growth are generally inhibited by low concentrations of digitonin ( 15 to $60 \mu \mathrm{g} / \mathrm{ml}$ ) whereas species that do not require sterol are inhibited only by concentrations in the range of 250 to $500 \mu \mathrm{g} / \mathrm{ml}$. The results of our experiments demonstrate this same relationship between digitonin sensitivity and cholesterol requirement in these anaerobic mycoplasmas.

With the present classification system (26), the anaerobic mycoplasmas described here would be assigned to both Acholeplasmataceae and Mycoplasmataceae because one family encompasses strains that require sterols and the other does not. The rumen mycoplasmas, however, resemble each other more closely than they resemble any other mycoplasmas that have been described, and it seems logical that they should not be separated at the family level based upon cholesterol dependency. A more reasonable solution for this dilemma is the establishment of a new genus for anaerobic mycoplasmas, the proposed genus to include both bacteriolytic and nonbacteriolytic strains as well as strains that either require or do not require sterols. The anaerobic nature of these organisms is a unique, important, stable characteristic; there is precedence for separation of bacteria at the genus level based upon their aerobic or anaerobic nature.

Studies on the relationships of these organisms based upon serologic characteristics using growth inhibition, tube agglutination, and gel diffusion tests will be presented in a separate publication (I. M. Robinson and K. Rhoades, unpublished data). This work demonstrated that these nonbacteriolytic mycoplasmas may be placed into two distinct groups, one including the sterol-requiring strains and the other including the non-sterol-requiring strains. These organisms also differ serologically from anaerobic bacteriolytic mycoplasmas $(20,21)$ and from Mycoplasma bovigenitalium PG 11, $\boldsymbol{M}$. agalactiae $\mathrm{B} 38, \boldsymbol{M}$. bovirhinis $\mathrm{FX} 1$, and Acholeplasma laidlawii PG 10. Data from serologic studies thus support the uniqueness of these organisms and the groupings we have made based upon cultural and biochemical properties.

In consideration of the foregoing, we propose that these organisms be placed in a new genus for anaerobic mycoplasmas, for which we propose the name Anaeroplasma.

\section{ACKNOWLEDGMENTS}

We are indebted to A. L. Baetz, A. D. Boothe, J. A Bucklin, R. M. Glazier, P. A. Pattee, M. Phillips, and A. 
E. Ritchie for invaluable assistance in developing certain aspects of, this work.

\section{REPRINT REQUESTS}

Address reprint requests to: Isadore $\mathrm{M}$. Robinson, National Animal Disease Center, P. O. Box 70, Ames, Iowa 50010.

\section{LITERATURE CITED}

1. Allison, M. J., J. A. Bucklin, and R. W. Dougherty. 1964. Ruminal changes after overfeeding with wheat and the effect of intraruminal inoculation on adaptation to a ration containing wheat. J. Anim. Sci. 23:1164-1171.

2. Barker, S. B., and W. H. Summerson. 1941. The colorimeteric determination of lactic acid in biological materials. J. Biol. Chem. 138:535-554.

3. Boivin, A., I. Mesrobeanu, and L. Mesrobeanu. 1933. Technique pour la preparation des polysaccharides microbiens specifiques. C. R. Soc. Biol. 113:490-492.

4. Boothe, A. D., M. J. Van Der Maaten, and W. A. Malmquist. 1970. Morphological variation of a syncytial virus from lymphosarcomatous and apparently normal cattle. Arch. Gesamte Virusforsch. 31:373-384.

5. Brenner, S., and R. W. Horne. 1959. A negative staining method for high resolution electron microscopy of viruses. Biochim. Biophys. Acta 34:103-110.

6. Bryant, M. P., and L. A. Burkey. 1953. Cultural methods and some characteristics of some of the numerous groups of bacteria in the bovine rumen. J. Dairy Sci. 36:205-217.

7. Bryant, M. P., and I. M. Robinson. 1961. An improved nonselective culture medium for ruminal bacteria and its use in determining diurnal variation in numbers of bacteria in the rumen. J. Dairy Sci. 44:1446-1456.

8. Bryant, M. P., and I. M. Robinson. 1962. Some nutritional characteristics of predominant culturable ruminal bacteria. J. Bacteriol. 84:605-614.

9. Burton, K, 1968. Determination of DNA concentration with diphenylamine, p. 163-166. In L. Grossman and K. Moldave (ed.), Methods in enzymology, vol. 12. Academic Press Inc., New York.

10. Caldwell, D. R., and M. P. Bryant. 1966. Medium without rumen fluid for nonselective enumeration and isolation of rumen bacteria. Appl. Microbiol. 14:794-801.

11. Hayes, F. N. 1963. Solutes and solvents for liquid scintillation counting. Packard technical bulletin no. 1 . Packard Instrument Co., Inc., Downers Grove, Ill.

12. Holdeman, L. V., and W. E. C. Moore (ed.). 1972. Anaerobic laboratory manual. Virginia Polytechnic Institute and State University, Blacksburg, Va.

13. Hungate, R. E. 1966. The rumen and its microbes. Academic Press Inc., New York.

14. McDonald, J. A., K. V. Speeg, Jr., and J. W. Campbell. 1972. Urease: a sensitive and specific radiometric assay. Enzymologia 42:1-9.
15. Marmur, J. 1961. A procedure for the isolation of deoxyribonucleic acid from microorganisms. J. Mol. Biol. 3:208-218.

16. Miura, K. 1967. Preparation of bacterial DNA by the phenol-pH-9-RNases method, p. 543-545. In L. Grossman and K. Moldave (ed.), Methods in enzymology, vol. 12. Academic Press Inc., New York.

17. Razin, S., and Z. Shafer. 1969. Incorporation of cholesterol by membranes of bacterial L-phase variants. J. Gen. Microbiol. 58:327-339.

18. Razin, S., and J. G. Tully. 1970. Cholesterol requirement of mycoplasmas. J. Bacteriol. 102:306-310.

19. Ritchie, A. E., and A. O. Fernelius. 1969. Characterization of bovine viral diarrhea viruses. Arch. Gesamte Virusforsch. 5:369-389.

20. Robinson, I. M., and M. J. Allison. 1975. Transfer of Acholeplasma bactoclasticum Robinson and Hungate to the genus Anaeroplasma (Anaeroplasma bactoclasticum [Robinson and Hungate] comb.nov.): emended description of the species. Int. J. Syst. Bacteriol. 25:182-186.

21. Robinson, J. P., and R. E. Hungate. 1973. Acholeplasma bactoclasticum sp. $\mathrm{n}$., an anaerobic mycoplasma from the bovine rumen. Int. J. Syst. Bacteriol. 23:171-181.

22. Schildkraut, C. L., J. Marmur, and P. Doty. 1962. Determination of the base composition of deoxyribonucleic acid from its buoyant density in $\mathrm{CsCl}$. J. Mol. Biol. 4:430-443.

23. Schubert, K., G. Rose, and C. Hörhold. 1969. Sterols in bacteria, p. 53-56. In K. Schubert (ed.), Symposium über biochemische aspekte der steriodforschung. Akademie-Verlag, Berlin.

24. Simmons, D. G., and P. D. Lukert. 1972. Isolation of an anaerobic mycoplasma from avian cell cultures and some of its effects of Marek's disease virus. Avian Dis. 16:521-528.

25. Smith, P. F., and G. H. Rothblat. 1960. Incorporation of cholesterol by pleuropneumonia-like organisms. J. Bacteriol. 80:842-850.

26. Subcomittee on the Taxonomy of Mycoplasmatales. 1972. Proposal for minimal standards for descriptions of new species of the order Mycoplasmatales. Int. J. Syst. Bacteriol. 22:184-188.

27. Vandemark, P. J. 1969. Respiratory pathways in the Mycoplasma, p. 491-501. In L. Hayflick (ed.), The Mycoplasmatales and the L-phase of bacteria. Appleton-Century-Crofts, New York.

28. Wainer, A. 1967. The chromatography of ninhydrin negative compounds on an amino acid analyzer column. J. Chromatogr. 26:48-53.

29. Ward, J. R., and C. H. Martin. 1962. Production of L-phase variants of bacteria with cycloserine. Proc. Soc. Exp. Biol. Med. 111:156-160.

30. Westphal, O., O. Luderitz, and F. Bister. 1952. Extraction of bacteria with phenol water. Z. Naturforsch. 7B:149-155. 